\title{
Blackberry Leaves as New Functional Food? Screening Antioxidant, Anti-Inflammatory and Microbiological Activities in Correlation with Phytochemical Analysis
}

Magdalena Paczkowska-Walendowska ${ }^{1, *(\mathbb{D}}$, Anna Gościniak ${ }^{1} \mathbb{D}$, Daria Szymanowska ${ }^{\mathbb{1}}$, Dominik Szwajgier ${ }^{3} \mathbb{D}$, Ewa Baranowska-Wójcik ${ }^{3}(\mathbb{D})$, Piotr Szulc ${ }^{4} \mathbb{D}^{\text {, }}$, Dagna Dreczka ${ }^{5}$, Marek Simon ${ }^{6}$ and Judyta Cielecka-Piontek ${ }^{1} \mathbb{D}$

1 Department of Pharmacognosy, Poznan University of Medical Sciences, Rokietnicka 3, 60-806 Poznan, Poland; annagos97@gmail.com (A.G.); jpiontek@ump.edu.pl (J.C.-P.)

2 Department of Biotechnology and Food Microbiology, Poznan University of Life Sciences, Wojska Polskiego 48, 60-627 Poznan, Poland; darszy@up.poznan.pl

3 Department of Biotechnology, Microbiology and Human Nutrition, University of Life Sciences in Lublin, Skromna 8, 20-704 Lublin, Poland; dominik.szwajgier@up.lublin.pl (D.S.); ewa.baranowska@up.lublin.pl (E.B.-W.)

4 Department of Agronomy, Poznan University of Life Sciences, Dojazd 11, 60-632 Poznan, Poland; piotr.szulc@up.poznan.pl

check for updates

Citation: Paczkowska-Walendowska M.; Gościniak, A.; Szymanowska, D.; Szwajgier, D.; Baranowska-Wójcik, E.; Szulc, P.; Dreczka, D.; Simon, M.; Cielecka-Piontek, J. Blackberry Leaves as New Functional Food? Screening Antioxidant,

Anti-Inflammatory and

Microbiological Activities in Correlation with Phytochemical Analysis. Antioxidants 2021, 10, 1945. https://doi.org/10.3390/antiox10121945

Academic Editor:

María Jesús Rodríguez-Yoldi

Received: 9 November 2021

Accepted: 1 December 2021

Published: 4 December 2021

Publisher's Note: MDPI stays neutral with regard to jurisdictional claims in published maps and institutional affiliations.

Copyright: (c) 2021 by the authors. Licensee MDPI, Basel, Switzerland. This article is an open access article distributed under the terms and conditions of the Creative Commons Attribution (CC BY) license (https:/ / creativecommons.org/licenses/by/ $4.0 /)$.
5 Department of Rehabilitation and Physiotherapy, Poznan University of Medical Sciences, 28 Czerwca 1956r. 135/147, 61-545 Poznan, Poland; dagna.dreczka@ump.edu.pl

6 Department of Pathophysiology, Poznan University of Medical Sciences, Rokietnicka 8, 60-806 Poznan, Poland; msimon@ump.edu.pl

* Correspondence: mpaczkowska@ump.edu.pl

Abstract: Blackberry fruits are recognized as functional foods while blackberry leaves are outside this classification and they also contain active compounds with health-promoting potential. Therefore, the aim of this study was the phytochemical analysis of blackberry leaves of varieties (Chester, Loch Ness, Loch Tay and Ruczaj) and screening of their biological activity (antioxidant potential, possibility of inhibition of enzymes, anti-inflammatory and microbial activity). The following compounds from selected groups: phenolic acids (caffeic acid, ellagic acid, gallic acid, syringic acid), flavonols (quercetin, kaempferol) and their glycosides (rutin, isoquercetin, hyperoside) and flavon-3-ols (catechin, epicatechin) were chromatographically determined in the aqueous and hydroalcoholic leaves extracts. All tested blackberry leaves extracts showed antioxidant effects, but the highest compounds content (TPC $=101.31 \mathrm{mg} \mathrm{GAE} / \mathrm{g}$ ) and antioxidant activity (e.g., DPPH IC $\mathrm{I}_{50}=57.37 \mu \mathrm{g} / \mathrm{mL}$; ABTS $\mathrm{IC}_{50}=24.83 \mu \mathrm{g} / \mathrm{mL} ;$ CUPRAC IC $50=62.73 \mu \mathrm{g} / \mathrm{mL} ;$ FRAP IC $50=39.99 \mu \mathrm{g} / \mathrm{mL}$ for hydroalcoholic extracts) was indicated for the Loch Tay variety. Blackberry leaf extracts' anti-inflammatory effect was also exceptionally high for the Loch Tay variety $\left(\mathrm{IC}_{50}=129.30 \mu \mathrm{g} / \mathrm{mL}\right.$ ), while leaves extracts of the Loch Ness variety showed a significant potential for microbial activity against Lactobacillus spp. and Candida spp. Summarizing, the best multidirectional pro-health effect was noted for leaves extracts of Loch Tay variety.

Keywords: blackberry; leaves; Loch Tay variety; agri-food waste; antioxidant activity; anti-inflammatory activity; microbiological activity

\section{Introduction}

At present, foods are intensively tested for additional physiological benefits that can reduce the risk of chronic disease or otherwise optimize health. With documented health benefits, such foods can be referred to as functional foods [1]. One such example could be blackberries, which are recognized worldwide as a functional food and their high interest is connected with the high content of polyphenols compounds, which greatly contribute to their organoleptic properties and health benefits [2]. 
In recent years, Europe has become one of the world leaders in the production of blackberries (Rubus fruticosus). The crops development is promoted by favorable climatic and soil conditions as well as the cultivators experience [3]. Farmers have generated a number of cultivars of $R$. fruticosus using traditional breeding procedures, which differ in fruit firmness, shape, size, flavor, color, weight, yield, ripening season, nutritional contents, and resistance to pests. The most well-known cultivars include Jumbo, Chester, Bartin, Ness, Bursa 1, Bursa 2, Bursa 3, Arapaho, Navaho, Thornfree, Chester Thornless, Dirksen Thornless, Cacanska Bestrna, Loch Ness, Cherokee, and Black Satin [4]. Notably, despite the great interest in blackberry fruits, also their leaves have been used in traditional remedies. Leaves are byproducts of berry cultivation and are often treated as waste when growing fruit. The use of agri-food waste products, such as leaves, seeds, bark and branches, is not a new approach, but becoming an increasingly important alternative to obtaining raw materials with significant economic potential [5-10]. Therefore, it is also worth looking at the content of bioactive compounds in the leaves and their application.

Phenolic acids (hydroxybenzoic and hydroxycinnamic acids and their derivatives), flavonoids, such as flavonols, flavanols, and anthocyanins, and tannins are all examples of polyphenols found in blackberries [2]. The compositions of the blackberry leaves are listed in Table 1.

Table 1. An overview of the distribution of polyphenols compounds [2].

\begin{tabular}{cc}
\hline & Compound Name \\
\hline Phenolic Acids & Neo-chlorogenic acid \\
& Caffeic acid \\
Gallic acid & p-coumaric acid \\
& Ellagic acid \\
Quercetin & Cuercetin-3-O-galactoside, hyperoside \\
Flavonols & Quercetin-3-O-glucuronide, miquelianin \\
& Kaempferol \\
& Catechin \\
Flavan-3-ols & Epicatechin \\
& Epicatechin gallate methyl gallate \\
Ellagitannins & Canguiin H-6 /Lambertianin C \\
Anthocyanins & Cyanidin-3-O-glucoside \\
\hline
\end{tabular}

Anti-microbial, antioxidant, anti-inflammatory, and anti-cancer activities are just some of the multiple biological effects attributed to flavonoids and other phenolic compounds. The majority of pharmacological effects may be traced back to phenolic compounds, which aid in the scavenging of free radicals that cause a variety of clinical and metabolic diseases [4]. Blackberry leaves provide extracts used in traditional medicine as a mouthwash against thrush, gum inflammations, mouth ulcers, and sore throat [11]. Finally, they have long been utilized to treat a variety of respiratory issues [11]. The tannins in blackberry leaves are responsible for some beneficial effects for diarrhea treatment and similar enteric disorders and as an astringent. However, tannins can cause liver damage if ingested in large amounts over long periods [12]. Blackberry leaves are known to eliminate free radicals that damage cells, and as antioxidants, they can help prevent lifestyle diseases. They also aid in the protection and strengthening of immunity, as well as lowering the risk of cancer [13].

Blackberry is one of the highest sources of anthocyanins, flavonol glycosides, and other phenols among common fruits and vegetables, contributing to its strong antioxidant potential. However, there is a scarcity of information on the chemical makeup of Rubus leaves. Despite the fact that the phenolic content of the leaves is affected by environmental factors and harvest maturity, it is critical to understand the chemical composition and 
anti-oxidant properties of the various Rubus species in order to use them selectively in the pharmaceutical and food industries [14].

To the best of our knowledge, no comparative studies have been carried out on the chemical composition of leaves of the new Rubus varieties. Consequently, the aim of the research was to identify polyphenolic compounds and their content, as well as their biological properties, including antioxidant, anticholinesterase, anti-inflammatory, and microbiological activity, which can be extremely valuable both in human health but also as an economic use of agri-food waste.

\section{Materials and Methods}

\subsection{Chemicals and Reagents}

Standards of phenolic acids: caffeic acid, ellagic acid, gallic acid, syringic acid; flavonols: quercetin, kaempferol, and their glycosides: rutin, isoquercetin, hyperoside; flavon-3-ols: catechin, epicatechin were obtained from Sigma-Aldrich (Poznan, Poland), as well as all reagents for antioxidant and anti-hyaluronidase activity assays: Folin-Ciocalteu's phenol reagent, sodium carbonate, 2,2-Diphenyl-1-picrylhydrazyl (DPPH), potassium persulfate $\left(\mathrm{K}_{2} \mathrm{~S}_{2} \mathrm{O}_{8}\right), 2,2^{\prime}$-Azino-bis(3-ethylbenzothiazoline-6-sulfonic acid) diammonium salt (ABTS, $\left.\mathrm{C}_{8} \mathrm{H}_{24} \mathrm{~N}_{6} \mathrm{O}_{6} \mathrm{~S}_{4}\right)$, neocuproine, ammonium acetate, copper(II) chloride $\left(\mathrm{CuCl}_{2} \cdot \mathrm{H}_{2} \mathrm{O}\right)$, sodium acetate trihydrate $\left(\mathrm{CH}_{3} \mathrm{COONa} \cdot 3 \mathrm{H}_{2} \mathrm{O}\right)$, 2,4,6-tris(2-pyridyl)-1,3,5-triazine (TPTZ, $\mathrm{C} 18 \mathrm{H} 12 \mathrm{~N} 6)$, iron(III) chloride hexahydrate $\left(\mathrm{FeCl}_{3} \cdot 6 \mathrm{H}_{2} \mathrm{O}\right)$, sodium chloride, bovine serum, hexadecyltrimethylammonium bromide (CTAB), and hyaluronic acid (HA). The following chemicals from Sigma-Aldrich (Poznan, Poland) were used: DMSO D4540, AChE C3389, BChE C7512, ATChI A5751, BTCh B3128, DTNB D8130, donepezil D6821, neostigmine N2001, magniflorine SMB00377, rivastigmine SML0881, eserine E8375, neocuproin N1501, $\mathrm{CuCl} 2$ 307483, TPTZ 93285, Trolox 238813, fluorescein 46955, $\mathrm{CoF}_{2} 236128$, linoleic acid L1376, Tween20 P1379, $\beta$-carotene C9750, Tween 80 P1754, ascorbic acid A92902, glutathione reductase G3664, glutathione (GSH) G4251, glutathione peroxidase G6137, nicotinamide adenine dinucleotide phosphate (NADPH) N5130, ethylenediaminetetraacetic acid (EDTA) E9884, glutathione disulfide (GSSG) G4626, superoxide dismutase (SOD) S5395, nitrobluetrazolium N6639, xanthine X0626, and xanthine oxidase X4875. 2,2'-Azobis(2amidinopropane) dihydrochloride (AAPH) was from Acros Organics (Poznan, Poland) (401560250), cyclooxygenase-2 (COX-2, human recombinant, 60122) and COX-2 activity assay kit (760151) were from Cayman Chemicals (Ann Arbor, Michigan, USA). Buffer salts, solvents and other reagents were from Sigma Aldrich and were at least of analytical grade. HPLC grade acetonitrile and methanol were obtained from Merck (Warsaw, Poland). Highquality pure water and ultra-high-quality pure water were prepared by using a Direct-Q 3 UV Merck Millipore purification system (Merck, Darmstadt, Germany).

\subsection{Preparation and Analysis of Rubi Folium Extract}

\subsubsection{Plan Material}

Blackberry leaves for the study were derived from the "Szynsad" Orchard Farm in Dąbrówka Nowa near Grójec Mazowieckie, Poland (51 $47^{\prime} 01^{\prime \prime}$ N 20 $43^{\prime} 04^{\prime \prime}$ E) in 2020. It was a plantation in the third year of cultivation. The basis of fertilization was chemical soil analysis for the assessment of basic nutrient contents. There was an abundance of soil phosphorus, potassium and magnesium in the spring (start of vegetation). At that time they were at the following levels: $69.0 \mathrm{mg} \mathrm{P} \cdot \mathrm{kg}^{-1}$ soil; $105.0 \mathrm{mg} \mathrm{K} \cdot \mathrm{kg}^{-1}$ soil; and $39.0 \mathrm{mg} \mathrm{Mg} \cdot \mathrm{kg}^{-1}$ soil, respectively. The mineral fertilization program was as follows: start of vegetation NPK 12-11-18+Mg, the start of flowering NK 14-24+Ca, the development of green parts of the plant NPK $14-1.5-7+\mathrm{Mg}+\mathrm{Fe}$, and flowering and fruit development $\mathrm{Ca}+\mathrm{K}$. Disease control on the blackberry plantation was carried out in accordance with the Plant Protection Program.

Leaf-blades of the following varieties were collected for the study:

- Rubus Chester-thornless variety, the mature shrub grows up to a height of $1.5 \mathrm{~m}$ high; the variety is susceptible to anthracnose, gray mold and verticillium wilt. 
- Rubus Loch Ness-thornless variety, the mature shrub grows up to a height of $5 \mathrm{~m}$, thermal and soil requirements of this variety are low.

- Rubus Loch Tay-thornless variety, the mature shrub grows up to a height of $1.5 \mathrm{~m}$, fruits on two-year-old shoots, average thermal and soil requirements.

- Rubus Ruczaj-thornless variety, the mature shrub grows to a height of approximately $2 \mathrm{~m}$, medium thermal and soil requirements, susceptible to gray mold, medium thermal and soil conditions.

\subsubsection{Extract Preparation}

$100.0 \mathrm{mg}$ of plant raw material was extracted with $5.0 \mathrm{~mL}$ of water or methanol and distilled water $(7: 3 \mathrm{v} / \mathrm{v})$ mixture at the temperature of $50{ }^{\circ} \mathrm{C}$ in an ultrasonic bath: three times for $30 \mathrm{~min}$. Extracts were concentrated to $10.0 \mathrm{~mL}$ to yield a stock solution $(10.0 \mathrm{mg}$ dry leaf $/ \mathrm{mL})$.

\subsubsection{Determination of Active Compounds Content in Extracts}

The concentrations of active substances were measured by using the HPLC-DAD (Dionex Thermoline Fisher Scientific, Waltham, MA, USA) with Chromeleon software version 7.0. Separations were performed on a LiChrospher RP-18 column, $5 \mu \mathrm{m}$ particle size, $250 \mathrm{~mm} \times 4 \mathrm{~mm}$ (Merck, Darmstadt, Germany). The detection was done with a diode array detector at a wavelength maxima $\left(\lambda_{\max }\right)$ of 270 and $360 \mathrm{~nm}$, depending on active compounds. The mobile phase was composed of formic acid $0.1 \%$ in water (A) and acetonitrile (B) with a gradient elution: 0-35 min, 2-20\% B; 35-55 min, 20-70\% B; $55 \mathrm{~min}$, $2 \% \mathrm{~B} ; 55-60 \mathrm{~min}, 2 \% \mathrm{~B}$, with mobile phase flow set at $1.0 \mathrm{~mL} / \mathrm{min}$. The column temperature was kept at $30^{\circ} \mathrm{C}$.

The presence of 11 active compounds (phenolic acids: caffeic acid, ellagic acid, gallic acid, syringic acid; flavonols: quercetin, kaempferol, and their glycosides: rutin, isoquercetin, hyperoside; flavon-3-ols: catechin, epicatechin) in the extracts was confirmed by comparison of retention time and UV spectra of particular substances; whereas, the quantitative assessment of the content included 7 actives (caffeic acid, ellagic acid, quercetin, kaempferol, rutin, hyperoside, epicatechin).

In terms of selectivity, linearity, intra- and inter-day accuracy, limits of detection (LOD), and quantitation, the HPLC-DAD method was validated according to the International Conference on Harmonization Guideline Q2 (LOQ) [15].

\subsubsection{Total Phenolic Content (TPC)}

Kikowska et al. [16] described the Folin-Ciocalteu method for determining TPC. To $25 \mu \mathrm{L}$ of the extracts or gallic acid solution (in concentration range $6.25-100 \mu \mathrm{g} / \mathrm{mL}$ ), $200 \mu \mathrm{L}$ of distilled water, $15 \mu \mathrm{L}$ of Folin-Ciocalteu reagent and $60 \mu \mathrm{L}$ of $20 \%$ sodium carbonate solution were added. In dark conditions, the plate was shaken for $5 \mathrm{~min}$ at room temperature at $600 \mathrm{rpm}$, then incubated for another $25 \mathrm{~min}$ at room temperature. Six replicates were used in the analysis. The total gallic acid content in the produced extracts was estimated using the standard substance's calibration curve and represented as milligrams of gallic acid equivalents (GAE) per $1 \mathrm{~g}$ of plant material.

\subsubsection{Antioxidant Activity}

Assay with 2,2-Diphenyl-1-picrylhydrazyl (DPPH)

A total of $25 \mu \mathrm{L}$ of extracts were combined with $175 \mu \mathrm{L}$ of DPPH solution $(3.9 \mathrm{mg} / 50 \mathrm{~mL}$ methanol). The reaction mixture was shaken and incubated at room temperature for $30 \mathrm{~min}$ in the dark. The absorbance of $25 \mu \mathrm{L}$ of water or a 3:7 $v / v$ water-methanol mixture and $175 \mu \mathrm{L}$ of methanol was measured at $517 \mathrm{~nm}$ against a blank $(25 \mu \mathrm{L}$ of water or a 3:7 $v / v$ water-methanol mixture and $175 \mu \mathrm{L}$ of methanol) [10]. Six replicates were used 
in the analysis. The percentage of DPPH scavenging activity was estimated using the following formula:

$$
D P P H_{\text {scavenging activity }}(\%)=\frac{A_{0}-A_{1}}{A_{0}} \times 100 \%
$$

where $A_{0}$ is the absorbance of the control, and $A_{1}$ is the absorbance of the sample.

The $\mathrm{IC}_{50}$ value, which corresponds to the concentration of the extract required to block radical production by $50 \%$, was calculated from the results.

\section{2,2-Azino-bis(3-ethylbenzothiazoline-6-sulfonic Acid) (ABTS) Radical Cation-Based Assays}

A volume of $200 \mu \mathrm{L}$ of the ABTS solution ( $0.0384 \mathrm{~g}$ ABTS dissolved in $10 \mathrm{~mL}$ of aqueous $2.45 \mathrm{mM}$ potassium persulfate solution left for $24 \mathrm{~h}$ ) was added to $50 \mu \mathrm{L}$ of the extract (in concentration range $0.08-2.50 \mathrm{mg} / \mathrm{mL}$ ) and then incubated in the dark condition for $10 \mathrm{~min}$ at room temperature. The absorbance was then measured at $\lambda=734 \mathrm{~nm}$ against a blank ( $50 \mu \mathrm{L}$ of water or a 3:7 $v / v$ water-methanol mixture and $200 \mu \mathrm{L}$ of water). Six replicates were used in the analysis. The equation was used to calculate the ability to remove free radicals $(\%)$ :

$$
\operatorname{ABTS}_{\text {scavenging activity }}(\%)=\frac{A_{A B T S}-A_{S}}{A_{A B T S}} \times 100 \%
$$

where $A_{A B T S}$ is the absorbance of ABTS cation radical solution, and $A_{S}$ is the sample absorbance.

The obtained $\mathrm{IC}_{50}$ values correspond to represent the quantity of antioxidant required to inhibit $50 \%$ of the radical.

\section{Oxygen Radical Absorbance Capacity (ORAC) Assay}

A sample of $10 \mu \mathrm{L}$ was tested by combining with $170 \mu \mathrm{L}$ of fluorescein $(0.00020941 \mathrm{mg}$ fluorescein $/ 10 \mathrm{~mL}, 75 \mathrm{mM}$ phosphate buffer, $\mathrm{pH} 7.4$ ) and incubated $20 \mathrm{~min}$ at $37^{\circ} \mathrm{C}$. Then, $20 \mu \mathrm{L}$ AAPH (0.14248 mg AAPH/mL buffer) was added and the fluorescence was read (excitation at $485 \mathrm{~nm}$ and emission at $520 \mathrm{~nm}$ ) at the start and after $1 \mathrm{~min}$, with continual shaking during the whole reaction, until stability. The blank sample contained phosphate buffer, instead of the sample. In addition, the background from the samples was measured (a mixture containing the studied sample and DDI water only). The activity was determined using a $50 \mu \mathrm{M}$ stock solution and 12 dilutions to obtain the Trolox equivalents [17].

\section{Effect on Superoxide Dismutase (SOD) Activity}

A sample of $0.05 \mathrm{~mL}$ was combined with $10 \mu \mathrm{L}$ SOD $(0.24 \mathrm{U}), 160 \mu \mathrm{L}$ nitrobluetatrazolium solution $(0.0025 \mathrm{M}), 205 \mu \mathrm{L}$ phosphate buffer $(0.2 \mathrm{M}, \mathrm{pH} 7.5), 30 \mu \mathrm{L}$ xanthine (150 $\mathrm{mM}$ in $1 \mathrm{M} \mathrm{NaOH})$ and $0.01 \mathrm{~mL}$ xanthine oxidase (0.065 $\mathrm{U})$. The difference in absorbance at $550 \mathrm{~nm}$ in tested samples vs. controls without studied samples was obtained after $20 \mathrm{~min}$ of incubation, and the effect on the enzyme was calculated using the following equation [18]:

$$
\operatorname{Inhibition}(\%)=100-100 \times \frac{A_{30 \mathrm{~min}}-A_{0 \min }}{A_{\text {control } 30 \mathrm{~min}}-A_{\text {control 0min }}}
$$

\section{Cupric Ion Reducing Antioxidant Capacity (CUPRAC) Assay}

A volume of $150 \mu \mathrm{L}$ CUPRAC reagent (equivalent volumes of $7.5 \mathrm{mM}$ neocuproine solution in $96 \%$ ethanol, acetate buffer $(\mathrm{pH}=7.0)$, and $10 \mathrm{mM} \mathrm{CuCl}_{2} \cdot \mathrm{H}_{2} \mathrm{O}$ solution) was added to $50 \mu \mathrm{L}$ extracts in a well of a 96-well plate for the CUPRAC assay [10]. The plate underwent shaking for $5 \mathrm{~min}$ before being incubated at room temperature for $25 \mathrm{~min}$ in the dark. The absorbance was then measured at $450 \mathrm{~nm}$. Six replicates of the analysis were carried out. The results were expressed as the $\mathrm{IC}_{0.5}$, which is the concentration of extract necessary to achieve an absorbance value of 0.5 . 
Ferric Ion Reducing Antioxidant Parameter (FRAP) Assay

The FRAP assay was carried out according to Kikowska et al. procedure's [16]. A volume of $25 \mu \mathrm{L}$ of the extract (in the concentration range of $0.08-2.50 \mathrm{mg} / \mathrm{mL}$ ) was added to $175 \mu \mathrm{L}$ of the freshly made FRAP mixture $(25 \mathrm{~mL}$ acetate buffer, $2.5 \mathrm{~mL}$ TPTZ solution, and $2.5 \mathrm{~mL} \mathrm{FeCl}_{3} \cdot 6 \mathrm{H}_{2} \mathrm{O}$ solution) and incubated in the dark for $30 \mathrm{~min}$ at $37^{\circ} \mathrm{C}$. The absorbance was then measured at $593 \mathrm{~nm}$. Six replicates were used in the analysis. The $\mathrm{IC}_{0.5}$ value, which corresponded to the concentration of extract necessary to achieve an absorbance value of 0.5 , was calculated.

\section{Hydroxyl Radical Averting Capacity (HORAC) Assay}

Fluorescein solution $(170 \mu \mathrm{L}, 60 \mathrm{nM})$ was combined with the sample $(0.01 \mathrm{~mL})$ and incubated at $37^{\circ} \mathrm{C}$ for $10 \mathrm{~min}$. Then, to the tested sample, $10 \mu \mathrm{L}$ of $27.5 \mathrm{mM} \mathrm{H}_{2} \mathrm{O}_{2}$ solution and $10 \mu \mathrm{L}$ of $\mathrm{CoF}_{2} \cdot 4 \mathrm{H}_{2} \mathrm{O}$ solution $(230 \mu \mathrm{M}$, containing $1 \mathrm{mg}$ of picolinic acid $/ \mathrm{mL})$ were added. The fluorescence was measured at the beginning and every 1 min after that until the process stabilized (excitation at $485 \mathrm{~nm}$ and emission at $520 \mathrm{~nm}$ ) (typically 5-10 $\mathrm{min}$ ). Instead of the sample, the blank sample contained phosphate buffer. In addition, the background from the samples was measured (a mixture containing the studied sample and DDI water only). The activity was measured in gallic acid equivalents (GAE), which were calculated using 15 gallic acid solutions (corresponding to $9.6-480.0 \mathrm{~g}$ of gallic acid $/ \mathrm{mL}$ ) as described previously [17].

\section{Effect on Glutathione Reductase (GR) and Glutathione Peroxidase (GPx) Activity}

The effect on glutathione reductase (GR) was performed as follows. The sample $(0.02 \mathrm{~mL})$ was mixed with $10 \mu \mathrm{L}$ EDTA solution, $12 \mu \mathrm{L}$ GSSG solution, and incubated for $5 \mathrm{~min}$ at $25^{\circ} \mathrm{C}$ before adding $4 \mu \mathrm{L}$ NADPH solution (all reagents were diluted in $0.1 \mathrm{mM}$ sodium phosphate buffer, $\mathrm{pH} 7.6)$ and recorded the first absorbance $(340 \mathrm{~nm})$. The reaction was then begun by adding $2 \mathrm{U}$ glutathione reductase $(2 \mu \mathrm{L} / \mathrm{L}), 177 \mu \mathrm{L} / \mathrm{L}$ of $0.1 \mathrm{mM}$ sodium phosphate buffer, and measuring the absorbance after $5 \mathrm{~min}$ at $25^{\circ} \mathrm{C}$. The following were the reagent concentrations in the final mixture ( $805 \mu \mathrm{L} / \mathrm{L}): 10 \mathrm{mM}$ GSSG, $0.5 \mathrm{mM}$ EDTA, and $10 \mathrm{mM}$ NADPH. Instead of the sample, a blank sample was created using the buffer, and the background was assessed (mixture containing studied sample and buffer only). In comparison to nmol of NADPH consumed/min in the blank (reagent) sample, one unit of enzyme activity was defined as nmol of NADPH consumed/min $\cdot \mathrm{mL}$ sample. [19].

The effect on glutathione peroxidase (GPx) was performed as follows. A volume of $8 \mu \mathrm{L}$ EDTA solution, $10 \mu \mathrm{L}$ glutathione reductase $(0.2 \mathrm{U}), 4 \mu \mathrm{L}$ GSH solution, $10 \mu \mathrm{L}$ glutathione peroxidase $(0.04 \mathrm{U}), 22 \mu \mathrm{L} \mathrm{H}_{2} \mathrm{O}_{2}$, and $332 \mu \mathrm{L} 50 \mathrm{mM}$ sodium phosphate, $\mathrm{pH}$ 7.0) were mixed with the sample $(0.020 \mathrm{~mL})$. A volume of $4 \mu \mathrm{L}$ of NADPH solution (N5130) was added to begin the reaction, and after $10 \mathrm{~min}$ of incubation at $25^{\circ} \mathrm{C}$, the decrease in absorbance $(340 \mathrm{~nm})$ was measured. All solutions were made in a $50 \mathrm{mM}$ buffer, with the following reagent concentrations in the final mixture: $1.5 \mathrm{mM} \mathrm{H}_{2} \mathrm{O}_{2}, 0.04 \mathrm{U}$ glutathione peroxidase, $1 \mathrm{mM}$ EDTA, $0.2 \mathrm{U}$ glutathione reductase, $2 \mathrm{mM} \mathrm{GSH}, 0.04 \mathrm{U}$ glutathione peroxidase, and $0.8 \mathrm{mM}$ NADPH. Instead of the sample, a blank sample was created using the buffer, and the background was assessed (mixture containing studied sample and buffer only). In comparison to nmol of NADPH consumed/min in the blank (reagent) sample, one unit of enzyme activity was defined as nmol of NADPH consumed $/ \mathrm{min} \cdot \mathrm{mL}$ sample [20].

\section{Inhibition of Lipid Peroxidation}

The conjugated diene technique was used to measure antioxidant activity in the linoleic acid model system (linoleic acid oxidation test). Linoleic acid $(800 \mathrm{mg})$ was freshly dissolved in pure $\mathrm{MeOH}(20 \mathrm{~mL})$ and combined with $200 \mathrm{~mL}$ of $0.2 \mathrm{M}$ sodium phosphate buffer (pH 6.5) and Tween 20. (6.5 mM conc. of Tween 20 was obtained). For $10 \mathrm{~min}$, the emulsion was sonicated. A volume of $0.2 \mathrm{~mL}$ of the sample was combined with $1.8 \mathrm{~mL}$ of linoleic acid emulsion and incubated at $37^{\circ} \mathrm{C}$. After $4 \mathrm{~h}$ of incubation, samples $(0.1 \mathrm{~mL})$ 
were obtained and mixed with $1.2 \mathrm{~mL}$ of $100 \% \mathrm{MeOH}$. At $234 \mathrm{~nm}$, the absorbance of a blank sample without an investigated solution was determined. The calibration curve was then created using ascorbic acid solutions (223.5-1676.3 $\mu \mathrm{g}$ ascorbic acid/mL) in the same way as the tested samples. The sample's background was measured at $234 \mathrm{~nm}$ (a mixture containing studied sample and buffer only) [21].

\section{$\beta$-Carotene Bleaching Test}

$\beta$-carotene $(7 \mathrm{mg})$ was combined with $350 \mathrm{~mL}$ linoleic acid and $2.8 \mathrm{~g}$ Tween 80 in $5 \mathrm{~mL}$ chloroform. Under vacuum $\left(40^{\circ} \mathrm{C}\right)$, chloroform was evaporated, and $100 \mathrm{~mL}$ of DDI water saturated with oxygen was added, followed by vigorous shaking. $\beta$-carotene/linoleic acid emulsion $(200 \mu \mathrm{L})$ was combined with the sample $(200 \mathrm{~L})$. At $463 \mathrm{~nm}$, the absorbance at zero time and the change in absorbance after $4 \mathrm{~h}$ at $50{ }^{\circ} \mathrm{C}$ were measured. Instead of the studied samples, a stock solution of ascorbic acid $(0.94 \mathrm{mg} / \mathrm{mL})$ was made, followed by a series of dilutions (9.4-94 $\mu \mathrm{g} / \mathrm{L})$, and utilized instead. The background of the samples was determined (a mixture containing the studied sample and DDI water only). The percent activity of samples was determined using blank samples containing only emulsion and DDI water [22].

To verify the statistical significance of the obtained results throughout antioxidant activity, the ANOVA test was used with the Statistica 12.0 software.

\subsubsection{Effect on Cholinesterase (ChE) Activity}

The colorimetric approach of Ellman [23] was employed, with the changes reported earlier [24]. After $5 \mathrm{~min}$, the tested sample $(10 \mu \mathrm{L})$ was combined with $20 \mu \mathrm{L}$ of AChE (or BChE) solution $(0.28 \mathrm{U} / \mathrm{mL}$ ), $175 \mu \mathrm{L}$ of $0.3 \mathrm{mmol} / \mathrm{L}$ DTNB (containing $10 \mathrm{mmol} / \mathrm{L}$ $\mathrm{NaCl}$ and $2 \mathrm{mmol} / \mathrm{L} \mathrm{MgCl2}$ ), and $110 \mu \mathrm{L}$ of Tris-HCl buffer (50 mmol/L, $\mathrm{pH} 8.0$ ) and completed with $35 \mu \mathrm{L}$ of ATChI (or BTCh) $(1.5 \mathrm{mmol} / \mathrm{L})$. In place of the examined sample, samples containing $35 \mu \mathrm{L}$ of Tris- $\mathrm{HCl}$ buffer were run in the same way ("blank" samples). Using "blank" samples containing ATCh (or BTCh) and DTNB completed to $345 \mu \mathrm{L}$ with Tris- $\mathrm{HCl}$ buffer, the increase in absorbance owing to spontaneous hydrolysis of the substrate was observed. The "false-positive" effect of the examined compounds was measured according to Rhee et al. [25] with slight adjustments, as stated earlier [24]: the "false-positive" sample was left for incubation after mixing the substrate with the enzyme and buffer. Then an examined sample and DTNB were added, and the absorbance was measured immediately.

The results were calculated using reference cholinesterase inhibitors (eserine, neostigmine, magniflorine, rivastigmine and donepezil). For this, 16 dilutions in pure DMSO $(2.57-41.14 \mu \mathrm{g} / \mathrm{mL})$ were made for each chemical. These solutions $(10 \mu \mathrm{L})$ were tested and calibration curves were created as mentioned above.

All solutions utilized in a series of assays were produced in the same buffer, and each sample was evaluated at least eight times. The background of the sample $(10 \mu \mathrm{L}$ mixed with $365 \mu \mathrm{L}$ of Tris buffer) was measured at $405 \mathrm{~nm}$ for calculations and removed. The test sample's absorbance was then subtracted from the "blank" sample's absorbance.

\subsubsection{Anti-Inflammatory Activity \\ Anti-Hyaluronidase Activity}

The hyaluronidase inhibition was determined by a turbidimetric method described by Studzińska-Sroka et al. [26]. Twenty-five $\mu \mathrm{L}$ enzyme (30 U/mL of acetate buffer $\mathrm{pH} 7.0$ ), $25 \mu \mathrm{L}$ acetate buffer (50 mM, pH 7.0, with $77 \mathrm{mM} \mathrm{NaCl}$ and $1 \mathrm{mg} / \mathrm{mL}$ of albumin), $15 \mu \mathrm{L}$ acetate buffer ( $\mathrm{pH} 4.5)$, and $10 \mu \mathrm{L}$ extracts were mixed, and incubated for $10 \mathrm{~min}$ at $37^{\circ} \mathrm{C}$. Then, $25 \mu \mathrm{L} \mathrm{HA}(0.3 \mathrm{mg} / \mathrm{mL}$ of acetate buffer $\mathrm{pH} 4.5)$ was added and incubated for $45 \mathrm{~min}$ at $37^{\circ} \mathrm{C}$. The undigested HA was precipitated with the addition of $200 \mu \mathrm{L} 2.5 \%$ CTAB in $2 \%$ $\mathrm{NaOH}$ ( $\mathrm{pH}$ 12). The mixture was incubated for $10 \mathrm{~min}$ at room temperature. The reaction mixture turbidance was measured as the absorbance at $\lambda=600 \mathrm{~nm}$. Three independent 
experiments were carried out in triplicate, obtaining 9 independent results. The inhibition percentage was calculated by using the following equation:

$$
\% \text { inhibition activity }=\frac{T_{S}-T_{C}}{T_{H}-T_{C}} \times 100 \%
$$

where $T_{S}$-absorbance of the enzyme $+\mathrm{HA}+$ extract, $T_{C}$-absorbance of the enzyme $+\mathrm{HA}$, and $T_{H}$-absorbance of the HA + extract.

The results are expressed as $\mathrm{IC}_{50}$ values, which corresponds to the extract concentration required for $50 \%$ of hyaluronidase inhibition. To verify the statistical significance of the obtained results, the ANOVA test was implemented with the Statistica 12.0 software.

\section{Effect on Cyclooxygenase-2 (COX-2) Activity}

For the assay, chemicals from the Cayman COX-2 Assay Kit were prepared according to the manufacturer's instructions and mixed with COX-2 enzyme (Human recombinant, Cayman No. 60122, pre-diluted 100-fold using $100 \mathrm{mM}$, pH 8.0 Tris buffer). A volume of $0.01 \mathrm{~mL}$ of the examined sample was combined with $0.12 \mathrm{~mL}$ of Tris buffer $(100 \mathrm{mM}$, $\mathrm{pH}$ 8.0), $0.01 \mathrm{~mL}$ hemin, and shaken for $5 \mathrm{~min}$ at $25^{\circ} \mathrm{C}$ before adding $0.02 \mathrm{~mL}$ colorimetric substrate and $0.02 \mathrm{~mL}$ arachidonic acid solution. Then, $0.02 \mathrm{~mL}$ COX-2 solution was added to start the reaction. The increase in absorbance during the room temperature incubation was measured at $590 \mathrm{~nm}$. Simultaneously, a negative (blank) sample (buffer instead of the examined sample) and a positive sample (COX-2 inhibitor DuP-697) were run. The background of the examined samples $(0.04 \mathrm{~mL}$ sample $+0.19 \mathrm{~mL}$ buffer) was also measured and accounted for in the calculations. Each sample was tested at least four times. The percentage of inhibition of enzyme activity was calculated (indicated by how many percent the activity was reduced in relation to the negative-blank sample for which the maximum activity was assumed as $100 \%$, under the conditions used in the method). In addition, enzyme inhibition was expressed as acetylsalicylic acid equivalent concentration $\left(\mathrm{mg} / \mathrm{cm}^{3}\right)$ in the samples. Acetylsalicylic acid solutions were produced at 14 concentrations $\left(0.2-10 \mathrm{mg} / \mathrm{cm}^{3}\right)$ for this purpose and examined in the same way as the tested samples.

\subsubsection{Microbiological Activity Inoculum Standardization}

For approximately $16 \mathrm{~h}$, all microorganism strains were inoculated in Müeller-Hinton broth ( $\mathrm{pH}$ 7.4). Using a spectrophotometer, the concentration of the suspensions were adjusted to 0.5 (optical density).

\section{Assay of Antibacterial Activity Using Agar Well Diffusion Method}

The Agar well diffusion method [27] was used to assess the antimicrobial activity of the crude and solvent extracts. Twenty $\mathrm{mL}$ of sterilized nutrient agar was put in sterile petri dishes. Using sterilized spreaders, $100 \mu \mathrm{L}$ of standardized inoculate of each isolate was inoculated on nutrient agar plates after solidification. Using a sterile gel puncher with a $6 \mathrm{~mm}$ diameter, the wells were punched over the agar plates. Then, $100 \mu \mathrm{l}$ of each extract were put in separate wells. The extracts were dissolved in $0.9 \%(v / v) \mathrm{NaCl}$, which served as a solvent extract negative control. Aqueous and extract concentrations in four distinct concentrations were examined. The plates were incubated for $24 \mathrm{~h}$ at $37^{\circ} \mathrm{C}$. To ensure dependability, triplets of the experiment were kept for each microorganism strain. The diameter of circular inhibitory zones produced around each well was measured in $\mathrm{mm}$ and recorded after incubation.

\section{Results and Discussion}

The search for new varieties of blackberry leaves is extremely necessary because of their unique properties. The experimental property screening studies of four Rubi folium varieties were divided into two areas: (1) evaluation of the composition of the obtained 
extracts and identification of compounds responsible for their biological activity, and (2) screening of the extracts' pharmacological activity.

Due to the different solubilities of active compounds in inorganic and organic solvents, two types of extracts, aqueous and hydroalcoholic, were prepared. Most of the active compounds are freely soluble in ethanol, hence the choice of methanol and distilled water $(7: 3 v / v)$ as the extraction mixture, while the second type is aqueous extracts because they are a simple, economic and ecological alternative to organic solvents. To identify and determine active compounds contained in plant material, a high-performance liquid chromatography method supported by a photodiode array detector was developed. The developed HPLC-DAD method confirmed the presence of selected phenolic compounds in blackberry extracts (Figure 1). The retention times of the selected peaks were compared with the retention times of the reference substances, as well as their UV spectra. Seven of eleven compounds identified in extracts were determined quantitatively in the prepared aqueous and hydroalcoholic extracts; caffeic acid, ellagic acid, epicatechin at $270 \mathrm{~nm}$, whereas quercetin, kaemferol, rutin and hyperoside at $360 \mathrm{~nm}$. Validation parameters for each standard are presented in Tables S1 and S2 in Supplementary Material. The content of active compounds is presented in Table 2.

Hyperoside and rutin were present in all investigated samples analyzed by the HPLCDAD method; these compounds, as poorly water-soluble, were obviously present in a greater amount in the hydroalcoholic extracts than the aqueous ones (Table 2). Detailed characteristics of the content of polyphenolic compounds of the described 4 varieties of blackberry leaves were reported for the first time in the presented studies; the species with the highest content of these compounds was blackberry leaves Loch Tay. Compared to other species described in the literature, the tested species contained more hyperoside in comparison with methanol extracts of $R$. fructicosus $(0.70 \%), R$. caesius $(0.46 \%), R$. nessensis $(1.05 \%), R$. odoratus $(0.60 \%), R$. fructicosus Gazda $(0.82 \%)$, and $R$. fructicosus Thomfree $(0.50 \%)$ [28].

Ellagic acid can occur in plants in the free form but it can also be in the form of ellagitannins from which it is released by hydrolysis. It may explain the much lower content of ellagic acid in the analyzed species compared to the data in the literature in methanol extracts after hydrochloric acid hydrolysis (extract concentration $2.0 \mathrm{mg} / \mathrm{mL}$ ) of $R$. fructicosus- $4.32 \%$, R. caesius - $4.15 \%$, R. nessensis- $6.89 \%$, R. odoratus-3.76\%, R. fructicosus Gazda-2.93\%, and R. fructicosus Thomfree-4.21\% [28].

The screening of biological effects of blackberry leaves extract was carried out in relation to (1) antioxidant, (2) anticholinesterase, (3) anti-inflammatory and (4) microbiological and properties.

It is advisable to utilize more than one antioxidant assay for determining the antioxidant activity of natural antioxidants in order to have a comprehensive understanding of the antioxidant properties of compounds and/or extracts. Therefore, in the presented study several methods expressing various aspects of the antioxidant action of polyphenols were used to provide a broader view of the antioxidant potential of blackberry leaves' extracts. The DPPH, ABST, ORAC and SOD methods measure the ability of an antioxidant to scavenge free radicals, which is the most physiologically important mechanism of antioxidant activity. The CUPRAC, FRAP and HORAC methods measure the metal-chelating activity of antioxidants and hence indicate the compounds protecting ability against formation of hydroxyl radical. Additionally, enzymes such as superoxide dismutase (SOD), glutathione peroxidase (GPx), and glutathione reductase (GR) are components of the cell's defense system to protect against oxidative damage, so they are useful models for assessing free radical scavenging by plant antioxidants. 
a

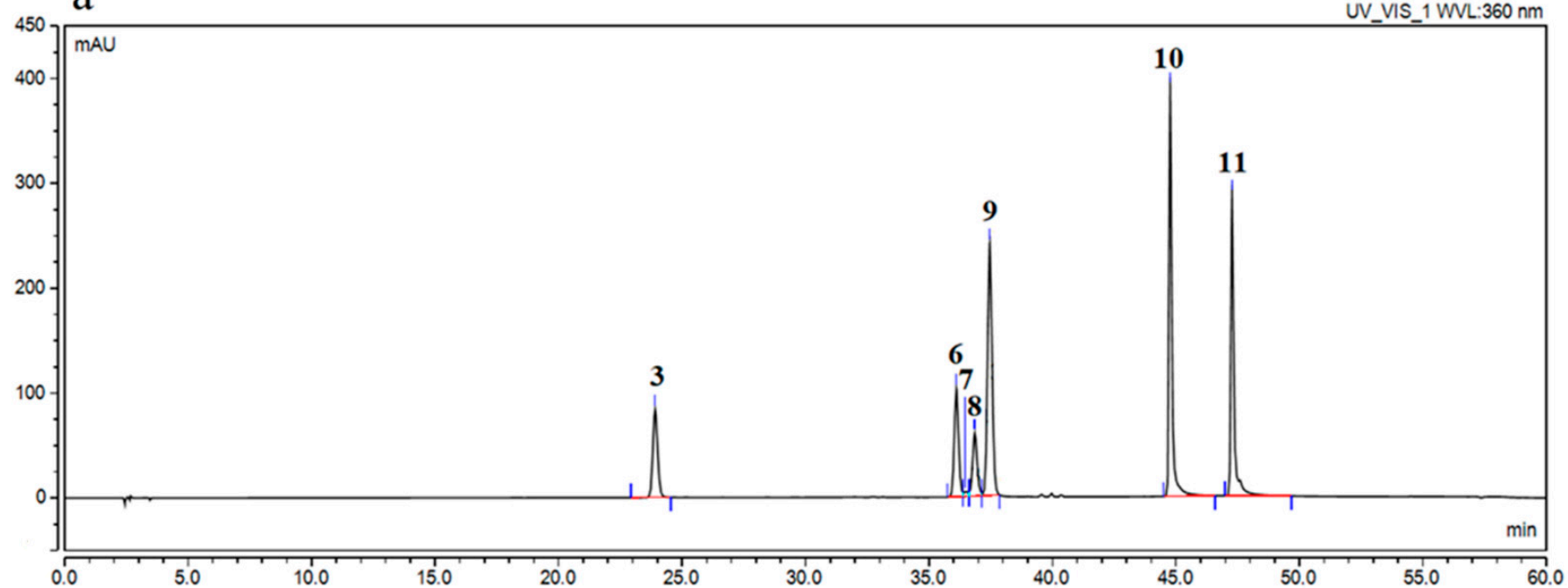

b

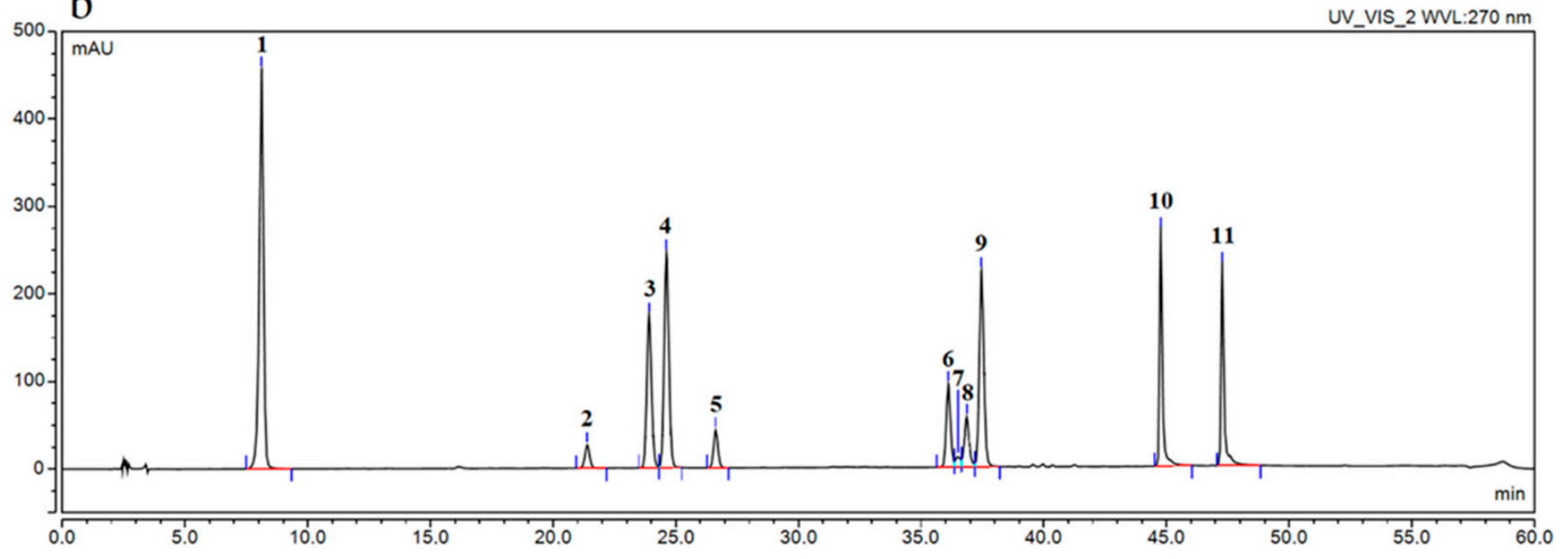

Figure 1. Chromatogram of phenolic compounds identified in blackberry leaves Loch Tay extracts: 1-gallic acid, 2-catechin, 3-caffeic acid, 4-syringic acid, 5-epicatechin, 6-rutin, 7-ellagic acid, 8-hyperoside, 9-isoquercetin, 10-quercetin, 11-kaempferol, at $360 \mathrm{~nm}(\mathbf{a})$ and $270 \mathrm{~nm}(\mathbf{b})$.

Table 2. The content of phenolic compounds in blackberry leaves aqueous and hydroalcoholic extracts.

\begin{tabular}{|c|c|c|c|c|c|c|c|c|}
\hline \multirow[t]{2}{*}{ Variet } & \multicolumn{2}{|c|}{ Chester } & \multicolumn{2}{|c|}{ Loch Ness } & \multicolumn{2}{|c|}{ Loch Tay } & \multicolumn{2}{|c|}{ Ruczaj } \\
\hline & $\begin{array}{c}\text { Water } \\
\text { Extract }\end{array}$ & $\begin{array}{l}\text { Hydroalcoholic } \\
\text { Extract }\end{array}$ & $\begin{array}{c}\text { Water } \\
\text { Extract }\end{array}$ & $\begin{array}{c}\text { Hydroalcoholic } \\
\text { Extract }\end{array}$ & Water Extract & $\begin{array}{c}\text { Hydroalcoholic } \\
\text { Extract }\end{array}$ & Water Extract & $\begin{array}{c}\text { Hydroalcoholic } \\
\text { Extract }\end{array}$ \\
\hline $\begin{array}{l}\text { Phenolic } \\
\text { Compound }\end{array}$ & \multicolumn{8}{|c|}{ Content ( $\mu \mathrm{g} / g$ Plant Material) } \\
\hline $\begin{array}{l}\text { Phenolic acids } \\
\text { caffeic acid } \\
\text { ellagic acid } \\
\text { Flavonols }\end{array}$ & $\begin{array}{l}18.35 \pm 1.57 \\
93.65 \pm 9.48\end{array}$ & $\begin{array}{c}17.12 \pm 0.81 \\
515.30 \pm 10.69\end{array}$ & $\begin{array}{c}20.65 \pm 0.46 \\
338.29 \pm 10.89\end{array}$ & $\begin{array}{c}1.77 \pm 0.03 \\
703.78 \pm 13.97\end{array}$ & $\begin{array}{l}606.62 \pm 4.22 \\
468.33 \pm 5.17\end{array}$ & $\begin{array}{c}255.25 \pm 6.62 \\
783.06 \pm 21.08\end{array}$ & $\begin{array}{c}85.89 \pm 5.15 \\
650.65 \pm 11.17\end{array}$ & $\begin{array}{c}55.86 \pm 6.59 \\
876.82 \pm 18.97\end{array}$ \\
\hline $\begin{array}{l}\text { quercetin } \\
\text { kaempferol } \\
\text { rutin } \\
\text { hyperoside }\end{array}$ & $\begin{array}{c}9.26 \pm 0.42 \\
0.12 \pm 0.05 \\
113.21 \pm 1.46 \\
4723.72 \pm 5.44\end{array}$ & $\begin{array}{c}23.61 \pm 0.86 \\
0.72 \pm 0.21 \\
117.09 \pm 7.15 \\
7094.32 \pm 9.93\end{array}$ & $\begin{array}{c}1.10 \pm 0.24 \\
1.67 \pm 0.29 \\
9.56 \pm 0.80 \\
2234.92 \pm 6.21\end{array}$ & $\begin{array}{c}15.98 \pm 0.41 \\
2.12 \pm 0.08 \\
28.69 \pm 2.40 \\
3775.87 \pm 11.25\end{array}$ & $\begin{array}{c}40.25 \pm 0.89 \\
3.49 \pm 0.27 \\
179.01 \pm 11.03 \\
29,990.78 \pm 14.07\end{array}$ & $\begin{array}{c}45.79 \pm 0.18 \\
4.46 \pm 0.16 \\
204.12 \pm 6.55 \\
30,854.28 \pm 96.37\end{array}$ & $\begin{array}{c}10.91 \pm 0.78 \\
0.37 \pm 0.07 \\
162.70 \pm 9.52 \\
5969.87 \pm 29.60\end{array}$ & $\begin{array}{c}30.25 \pm 0.24 \\
1.69 \pm 0.25 \\
445.21 \pm 32.02 \\
8047.17 \pm 14.39\end{array}$ \\
\hline $\begin{array}{l}\text { Flavon-3-ols } \\
\text { epicatechin }\end{array}$ & $35.07 \pm 0.99$ & $598.91 \pm 16.76$ & $4.67 \pm 1.30$ & $\begin{array}{l}157.14 \pm 8.94 \\
\text { content }(\%\end{array}$ & $\begin{array}{l}416.04 \pm 19.19 \\
\text { f dry weight) }\end{array}$ & $703.96 \pm 4.28$ & $77.03 \pm 7.88$ & $961.14 \pm 29.40$ \\
\hline $\begin{array}{c}\text { Phenolic acids } \\
\text { ellagic acid } \\
\text { Flavonols }\end{array}$ & $0.01 \pm 0.01$ & $0.05 \pm 0.01$ & $0.03 \pm 0.01$ & $0.07 \pm 0.01$ & $0.05 \pm 0.01$ & $0.08 \pm 0.01$ & $0.07 \pm 0.01$ & $0.09 \pm 0.01$ \\
\hline $\begin{array}{l}\text { rutin } \\
\text { hyperoside } \\
\text { Flavon-3-ols }\end{array}$ & $\begin{array}{l}0.01 \pm 0.01 \\
0.47 \pm 0.01\end{array}$ & $\begin{array}{l}0.01 \pm 0.01 \\
0.71 \pm 0.01\end{array}$ & $\begin{array}{c}>0.01 \\
0.22 \pm 0.01\end{array}$ & $\begin{array}{c}>0.01 \\
0.38 \pm 0.01\end{array}$ & $\begin{array}{l}0.02 \pm 0.01 \\
3.00 \pm 0.01\end{array}$ & $\begin{array}{l}0.02 \pm 0.01 \\
3.09 \pm 0.01\end{array}$ & $\begin{array}{l}0.02 \pm 0.01 \\
0.60 \pm 0.01\end{array}$ & $\begin{array}{l}0.04 \pm 0.01 \\
0.80 \pm 0.01\end{array}$ \\
\hline epicatechin & $>0.01$ & $0.06 \pm 0.01$ & $>0.01$ & $0.02 \pm 0.01$ & $0.04 \pm 0.01$ & $0.07 \pm 0.01$ & $>0.01$ & $0.10 \pm 0.01$ \\
\hline
\end{tabular}


Total phenolic content (TPC) was determined using the Folin-Ciocalteu method; obviously, a statistically higher content was found for hydroalcoholic extracts compared to water extracts (Table 3, extract concentration $10 \mathrm{mg} / \mathrm{mL}$ ). Loch Tay species showed the highest TPC among 4 tested species. The obtained phosphate extracts ( $2 \mathrm{~g}$ of leaf samples extracted with $15 \mathrm{~mL}$ of phosphate buffer $(75 \mathrm{mM}, \mathrm{pH} 7.0)$ using homogenizer; extract concentration $133.3 \mathrm{mg} / \mathrm{mL}$ ) exhibited lower TPC (blackberry Chester Thornless$82.8 \mathrm{mg} / \mathrm{g}$, Hull Thornless-74.0 mg/g and Triple Crown—91.0 mg/g) comparing to those tested in the presented work [29]. Moreover, investigations whether leaf age might have an effect on TPC, previous studies have shown that TPC is much higher in young leaves (from the upper part of shoots or stems) compared to older ones (from the lower part of shoots or stems) [29]. Polyphenolic composition and its antioxidant activity was described for blackberry pomace Chester (Soxhlet extractor, with $80 \%$ ethanol $(v / v)$ ), and it showed lower TPC compared to the leaf extracts tested in this study [30].

Table 3. Antioxidant activity of blackberry leaves aqueous and hydroalcoholic extracts.

\begin{tabular}{|c|c|c|c|c|c|c|c|}
\hline & $\begin{array}{c}\text { TPC } \\
(\mathrm{mg} \mathrm{GAE} / \mathrm{g}) \text { * }\end{array}$ & $\begin{array}{c}\text { DPPH } \\
\text { IC }_{50}(\mu \mathrm{g} / \mathrm{mL})\end{array}$ & $\begin{array}{c}\text { ABTS } \\
\text { IC }_{50}(\mu \mathrm{g} / \mathrm{mL})\end{array}$ & $\begin{array}{c}\text { CUPRAC } \\
\text { IC }_{0.5}(\mu \mathrm{g} / \mathrm{mL})\end{array}$ & $\begin{array}{c}\text { FRAP } \\
\text { IC }_{0.5}(\mu \mathrm{g} / \mathrm{mL})\end{array}$ & $\begin{array}{c}\text { HORAC } \\
\text { Equivalent } \\
\text { Gallic Acid } \\
\text { Concentration } \\
\left(\mu \mathrm{g} / \mathrm{cm}^{3}\right)\end{array}$ & $\begin{array}{c}\text { ORAC } \\
\text { Equivalent } \\
\text { Trolox } \\
\text { Concentration } \\
(\mu \mathrm{M})\end{array}$ \\
\hline \multicolumn{8}{|l|}{$\begin{array}{l}\text { Water } \\
\text { extracts }\end{array}$} \\
\hline Chester & $42.86 \pm 0.71$ & $99.37 \pm 2.47$ & $69.83 \pm 1.15$ & $175.80 \pm 9.23$ & $98.66 \pm 2.60$ & $\mathrm{n} / \mathrm{a}$ & $\mathrm{n} / \mathrm{a}$ \\
\hline Loch Ness & $29.89 \pm 0.19$ & $194.8 \pm 5.59$ & $81.73 \pm 2.31$ & $242.80 \pm 3.12$ & $112.07 \pm 3.49$ & $\mathrm{n} / \mathrm{a}$ & $\mathrm{n} / \mathrm{a}$ \\
\hline Loch Tay & $71.29 \pm 2.67$ & $76.70 \pm 3.92$ & $39.37 \pm 1.82$ & $103.87 \pm 11.94$ & $58.91 \pm 1.80$ & $\mathrm{n} / \mathrm{a}$ & $\mathrm{n} / \mathrm{a}$ \\
\hline Ruczaj & $69.34 \pm 1.89$ & $90.80 \pm 1.31$ & $49.27 \pm 1.21$ & $132.67 \pm 7.94$ & $82.51 \pm 4.20$ & $\mathrm{n} / \mathrm{a}$ & $\mathrm{n} / \mathrm{a}$ \\
\hline \multicolumn{8}{|l|}{$\begin{array}{l}\text { Hydroalcoholic } \\
\text { extracts }\end{array}$} \\
\hline Chester & $92.42 \pm 1.14$ & $66.67 \pm 1.27$ & $30.40 \pm 2.15$ & $72.80 \pm 3.16$ & $45.20 \pm 0.63$ & $120.80 \pm 8.20$ & $30.40 \pm 3.10$ \\
\hline Loch Ness & $69.44 \pm 3.80$ & $71.37 \pm 2.19$ & $35.10 \pm 1.32$ & $105.7 \pm 3.89$ & $47.10 \pm 3.10$ & $115.60 \pm 10.3$ & $36.20 \pm 1.00$ \\
\hline Loch Tay & $101.31 \pm 0.11$ & $57.37 \pm 3.61$ & $24.83 \pm 0.23$ & $62.73 \pm 3.89$ & $39.99 \pm 0.58$ & $121.10 \pm 11.2$ & $34.70 \pm 2.20$ \\
\hline Ruczaj & $95.55 \pm 2.09$ & $59.4 \pm 0.87$ & $28.67 \pm 1.72$ & $65.63 \pm 2.91$ & $39.44 \pm 1.61$ & $101.50 \pm 4.20$ & $42.00 \pm 2.40$ \\
\hline
\end{tabular}

Data expressed as mean \pm SD. ${ }^{*}$ Data expressed as miligrams of gallic acid equivalents (GAE) per $1 \mathrm{~g}$ of plant material. The best values (the TPC and the lowest $\mathrm{IC}_{50}$ or $\mathrm{IC}_{0.5}$ ) are shown in bold. $\mathrm{n} / \mathrm{a}$-non applicable.

The TPC is highly correlated with antioxidant activity. Obviously, hydroalcoholic extracts exhibited higher antioxidant activity compared to water ones, due to higher TPC and higher individual polyphenolic compounds' content. The highest antioxidant activity exhibited Loch Tay species, which was confirmed by 4 independent methods (Tables 3 and 4). Comparing water extracts with those obtained previously (extract concentration $20.0 \mathrm{mg} / \mathrm{mL}$ ), TPC for blackberry leaves was 75.4 and antioxidant activity obtained using DPPH was 125.2 and FRAP-36.7. Comparing those results with water green tea extract, known as a rich antioxidant source (TPC - 84.8, DPPH—175.2, FRAP—47.0) [31], it could be concluded that blackberry Loch Tay leaves water extract also shows very good antioxidant activity and could be used as an antioxidant agent. Testing the ability to inhibit GP and GPx (Table 4), we noticed that the differences in activity between cultivars were small and statistically insignificant, therefore it was not possible to select the best cultivars on the basis of these studies alone; however, the results showed the high antioxidant potential of the extracts.

The fact that ellagic acid, hyperoside and epicatechin were detected in the extracts in the highest amounts, also guarantees the antioxidant activity of the extracts, both for the water and alcohol-based cases. Ellagic acid exhibits antioxidant, anti-mutagenic, anti-inflamatory as well cardioprotective properties [32]. In addition to the significant scavenging of DPPH free radicals by ellagic acid, it also inhibited the lipid peroxides production in V79-4 cells exposed to hydrogen peroxide. Ellagic acid has also been found to increase the activity of the three antioxidant enzymes SOD, CAT and GPX, which are altered in various diseases involving free radicals [33]. Hyperoside is also believed to be effective in protecting cells against oxidative stress through the induction of HO-1. Additionally, it elevated Nrf2 levels and its antioxidant response element binding activity 
was modulated by pre-ERK; also it activated ERK and restored cell viability that had been reduced by hydrogen peroxide [34]. Catechin and epicatechin, included to flavon-3-ols, are antioxidants which influence plasma antioxidant biomarkers and energy metabolism [35].

Table 4. Antioxidant activity of blackberry leaves hydroalcoholic extracts.

\begin{tabular}{|c|c|c|c|c|c|c|c|}
\hline & $\begin{array}{l}\text { Effect on } \\
\text { SOD } \\
\text { Activity }\end{array}$ & & $\begin{array}{c}\text { Effect on GR } \\
\text { and GPx } \\
\text { Activity }\end{array}$ & & & $\begin{array}{c}\text { Linoleic } \\
\text { Acid } \\
\text { Oxidation }\end{array}$ & $\begin{array}{l}\beta \text {-Carotene } \\
\text { Oxidation }\end{array}$ \\
\hline & $\begin{array}{c}\text { Enzyme } \\
\text { Inhibition } \\
(\%)\end{array}$ & $\begin{array}{c}\text { GR } \\
\text { Inhibition } \\
(\%)\end{array}$ & $\begin{array}{c}\text { GR } \\
\text { Inhibitory } \\
\text { Activity ( } \mu \mathrm{mol} \\
\text { Consumed } \\
\text { NADPH/min } \\
\text { Incubation) }\end{array}$ & $\begin{array}{c}\text { GPx } \\
\text { Inhibition } \\
(\%)\end{array}$ & $\begin{array}{c}\text { GPx } \\
\text { Inhibitory } \\
\text { Activity (nmol } \\
\text { Consumed } \\
\text { NADPH/min } \\
\text { Incubation) }\end{array}$ & $\begin{array}{l}\text { Equivalent } \\
\text { Ascorbic } \\
\text { Acid Con- } \\
\text { centration } \\
\text { (mg/mL) }\end{array}$ & $\begin{array}{l}\text { Equivalent } \\
\text { Ascorbic } \\
\text { Acid Con- } \\
\text { centration } \\
(\mu \mathrm{g} / \mathrm{mL})\end{array}$ \\
\hline \multicolumn{8}{|c|}{$\begin{array}{l}\text { Hydroalcoholic } \\
\text { extracts }\end{array}$} \\
\hline $\begin{array}{l}\text { Chester } \\
\text { Loch Ness } \\
\text { Loch Tay } \\
\text { Ruczaj }\end{array}$ & $\begin{array}{l}18.3 \pm 1.5 \\
30.2 \pm 2.5 \\
27.6 \pm 2.0 \\
16.4 \pm 4.5\end{array}$ & $\begin{array}{l}44.3 \pm 3.2 \\
\mathbf{5 6 . 7} \pm \mathbf{2 . 1} \\
53.2 \pm 3.1 \\
\mathbf{5 8 . 4} \pm \mathbf{1 . 8}\end{array}$ & $\begin{array}{l}1.7 \pm 0.2 \\
2.2 \pm 0.1 \\
2.1 \pm 0.3 \\
2.3 \pm 0.3\end{array}$ & $\begin{array}{l}45.8 \pm 3.2 \\
46.9 \pm 2.4 \\
42.0 \pm 3.3 \\
33.4 \pm 1.2\end{array}$ & $\begin{array}{l}91.3 \pm 4.6 \\
93.5 \pm 3.5 \\
83.7 \pm 4.7 \\
66.6 \pm 2.1\end{array}$ & $\begin{array}{l}\mathbf{2 . 0 4} \pm \mathbf{0 . 1 2} \\
2.51 \pm 0.04 \\
\mathbf{2 . 1 8} \pm \mathbf{0 . 1 7} \\
\mathbf{2 . 1 1} \pm \mathbf{0 . 0 6}\end{array}$ & $\begin{array}{l}\mathbf{1 7 . 0} \pm \mathbf{3 . 2} \\
28.5 \pm 1.7 \\
24.4 \pm 2.1 \\
\mathbf{1 9 . 6} \pm \mathbf{1 . 8}\end{array}$ \\
\hline
\end{tabular}

Data expressed as mean \pm SD. The best values are shown in bold.

All the antioxidant activity data were summarized in the spider chart in Figure 2a,b. The data clearly show the outstanding antioxidant properties of the Loch Tay variety.
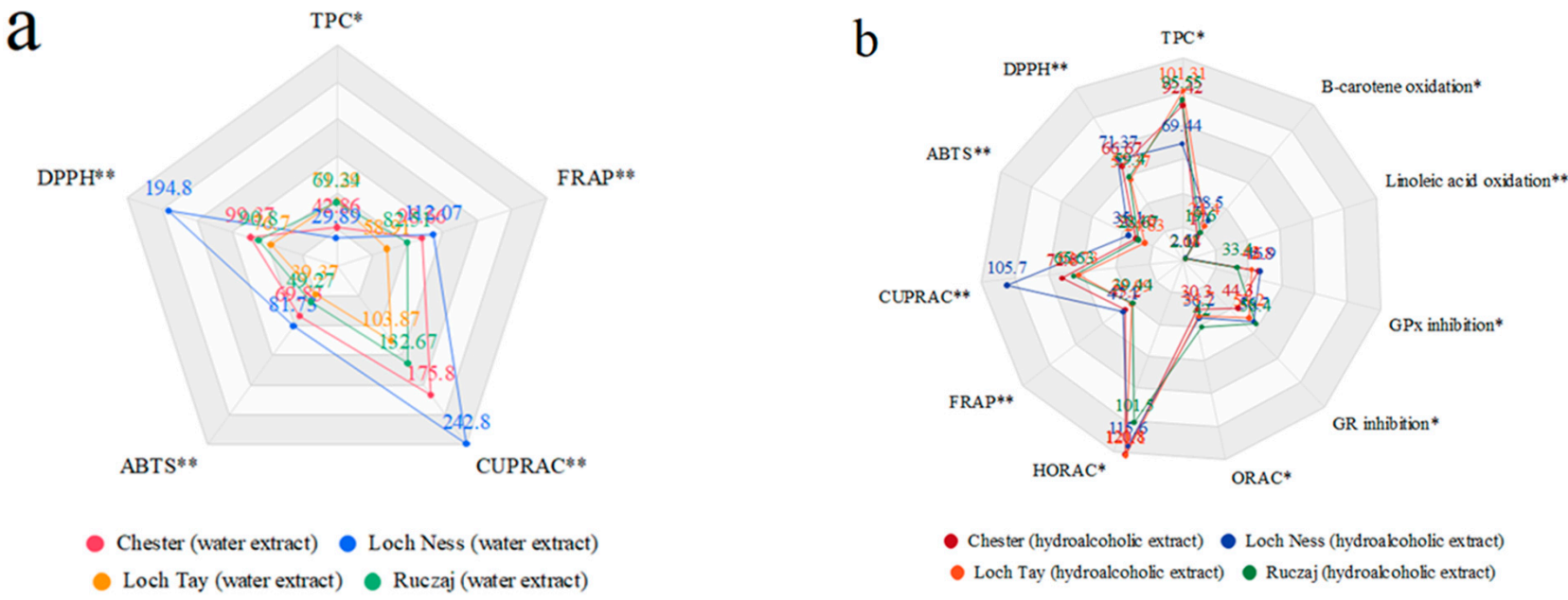

Figure 2. TPC in correlation with summarized antioxidant activity of blackberry leaves water (a) and hydroalcoholic (b) extracts. * the higher the value, the higher the activity. ${ }^{* *}$ the lower the value, the higher the activity.

Polyphenols can operate as antioxidants, in addition to their traditional antioxidant activity, by influencing intracellular redox balance through alternative methods such as inhibiting pro-oxidative enzymes such as lipoxygenase. Such effects could point to the use of blackberry leaf extracts in the prevention of neurodegenerative illnesses on a case-bycase basis. The presented study showed the ability to inhibit butyrylcholinesterase (BChE) by Loch Ness hydroalcoholic extracts (Table 5 ). Phenolic acids and flavonoids are known compounds with anticholinesterase activity [36,37], which confirms the extract activity. Therefore, the use of blackberry leaves is suggested to prevent neurodegenerative diseases such as Alzheimer's disease [4]. 
Table 5. Effect on BChE activity.

\begin{tabular}{cccccc}
\hline \multirow{2}{*}{ Sample } & \multicolumn{5}{c}{ Equivalent Reference Concentration $(\mu \mathrm{g} / \mathrm{mL})$} \\
& Neostigmine & Magniflorine & Donepezil & Eserine & Rivastigmine \\
\hline $\begin{array}{c}\text { Hydroalcoholic extract } \\
\text { Loch Ness }\end{array}$ & $2.2 \pm 0.1$ & $6.9 \pm 0.1$ & $1.2 \pm 0.0$ & $1.4 \pm 0.1$ & $11.2 \pm 0.1$ \\
\hline
\end{tabular}

In addition to the antioxidant activity of the polyphenols present in blackberry, there are reports on its anti-inflammatory activity, expressed by inhibiting the hyaluronidase as well as cyclooxygenase activity [38]. Hyaluronidases are known as pro-inflammatory agents; hence, hyaluronidase degradation appears critical and imperative in several pathological conditions [39]. The anti-hyaluronidase activity was measured for all 4 species of water extracts. Due to the specifics of the study, the experiment could not be performed for the hydroalcoholic extracts. The highest activity was demonstrated by Loch Tay and Ruczaj varieties, and the difference between those two was not statistically significant (Table 6). There are no literature data on the anti-hyaluronidase activity of other blackberry leaves varieties; hence it is not possible to compare the results with the previous ones. COX-2 inhibition was similar in the case of all tested variants (Table 6).

Table 6. Anti-inflammatory activity of blackberry leaves extracts.

\begin{tabular}{|c|c|c|c|c|}
\hline \multicolumn{3}{|c|}{$\begin{array}{c}\text { Anti-Hyaluronidase } \\
\text { Activity }\end{array}$} & \multicolumn{2}{|c|}{ Effect on COX-2 Activity } \\
\hline \multicolumn{3}{|c|}{$\mathrm{IC}_{50}(\mu \mathrm{g} / \mathrm{mL})$} & $\begin{array}{c}\text { Equivalent } \\
\text { Acetylsalicylic Acid } \\
\text { Concentration }\left(\mathrm{mg} / \mathrm{cm}^{3}\right)\end{array}$ & $\begin{array}{c}\text { COX-2 } \\
\text { Inhibition } \\
(\%)\end{array}$ \\
\hline Water extracts & \multicolumn{3}{|c|}{ Hydroalcoholic extract } & \\
\hline Chester & $160.69 \pm 15.20$ & Chester & $3.23 \pm 0.1$ & $84.6 \pm 3.5$ \\
\hline Loch Ness & $180.09 \pm 9.14$ & Loch Ness & $3.22 \pm 0.1$ & $82.1 \pm 3.2$ \\
\hline Loch Tay & $129.30 \pm 3.27$ & Loch Tay & $3.22 \pm 0.0$ & $82.1 \pm 2.0$ \\
\hline Ruczaj & $127.36 \pm 4.13$ & Ruczaj & $3.23 \pm 0.0$ & $84.6 \pm 1.6$ \\
\hline
\end{tabular}

Data expressed as mean $\pm \mathrm{SD}$. The best values (the lowest $\mathrm{IC}_{50}$ and the highest COX-2 inhibition) are shown in bold.

Again, the most abundant compounds in the extracts, ellagic acid, hyperoside and epicatechin, are suspected of having anti-inflammatory effects, as confirmed in previous studies involving standards. Ellagic acid has been assigned as an anti-inflammatory agent that acts on several inflammatory mediators [40], including concentration-dependent inhibition of the 12-lipoxygenase isoform [41]. Also, quercetin derivatives i.e., rutin, hyperoside and isoquercetin, show similar properties [42]. Hyperoside has been reported to be anti-inflammatory by inhibiting arachidonic acid-induced edema and croton oilinduced edema. It also inhibited the COX-2 and hyaluronidase enzymes and suppressed the production of IL-6, TNF and NO in the peritoneal macrophages of LPS-stimulated mice [43]. Moreover, many in vitro and in vivo studies using various tissues confirm the anti-inflammatory effects of epicatechin by reducing activation of the NF- $\mathrm{kB}$ signaling pathway [44].

The last stage of the research involved the assessment of the influence of blackberry leaves extracts on microorganisms. The antimicrobial effect of blackberry leaves' extracts was determined by inhibition of growth for both health-promoting (Lactobacillus spp. and Bacillus spp.) and potentially pathogenic microorganisms (G. vaginalis, S. agalactiae, S. aureus, E. coli, P. aeruginosa, S. typhimurium and Candida spp.) with extensive review of the activity for bacteria with a division for those living in the digestive tract (e.g., Lactobacillus spp. and E. coli), genital tract (e.g., G. vaginalis and S. agalactiae), on the skin (e.g., S. aureus), and also those that contribute to the formation of dental plaque and other oral diseases (e.g., Candida spp. and S. aureus). The microbiological activity of berries has been proven in past years, which was also demonstrated in this study [45-47]. So far, no similar studies 
have been carried out with the use of the studied varieties; therefore, it is difficult to refer directly to the literature data. Obviously, higher activity was obtained in the case of the hydroalcoholic extracts than in the water extracts (Figures 3 and 4). Microbiological activity is widely associated with polyphenols' strong anti-microbiological properties, which are also present in blackberry leaves extracts [48-50]. The lower activity of the Loch Tay and Ruczaj cultivars against probiotic bacteria (Lactobacillus spp.) confirms the hypothesis about the possible modification of the bacterial profile by blueberries. This is possible by increasing the number of beneficial bacteria and thereby improving gut health, which has also been proven for blackberries [45]. The potential of anthocyanin-rich blueberry extract has also been shown to reduce the adhesion of many pathogenic bacteria while reducing the infection probability [46]. Also, in this study, the blackberry leaves extracts showed a strong inhibition of e.g., E. coli or Candida spp. growth, the strongest in the case of the Loch Ness variety, which may suggest their extraordinary usefulness in inhibiting the infections' development both in the gastrointestinal tract and in the oral cavity. In an earlier study by González et al., the antibacterial effects of blackberry extract against $P$. gingivalis, F. nucleatum and S. mutans were demonstrated [51]. Combined with anti-plaque activity by inhibiting the Candida spp. adhesion and previously demonstrated strong antioxidant and anti-inflammatory properties, blackberry extracts are a promising method for the prevention and/or treatment of periodontal infections.

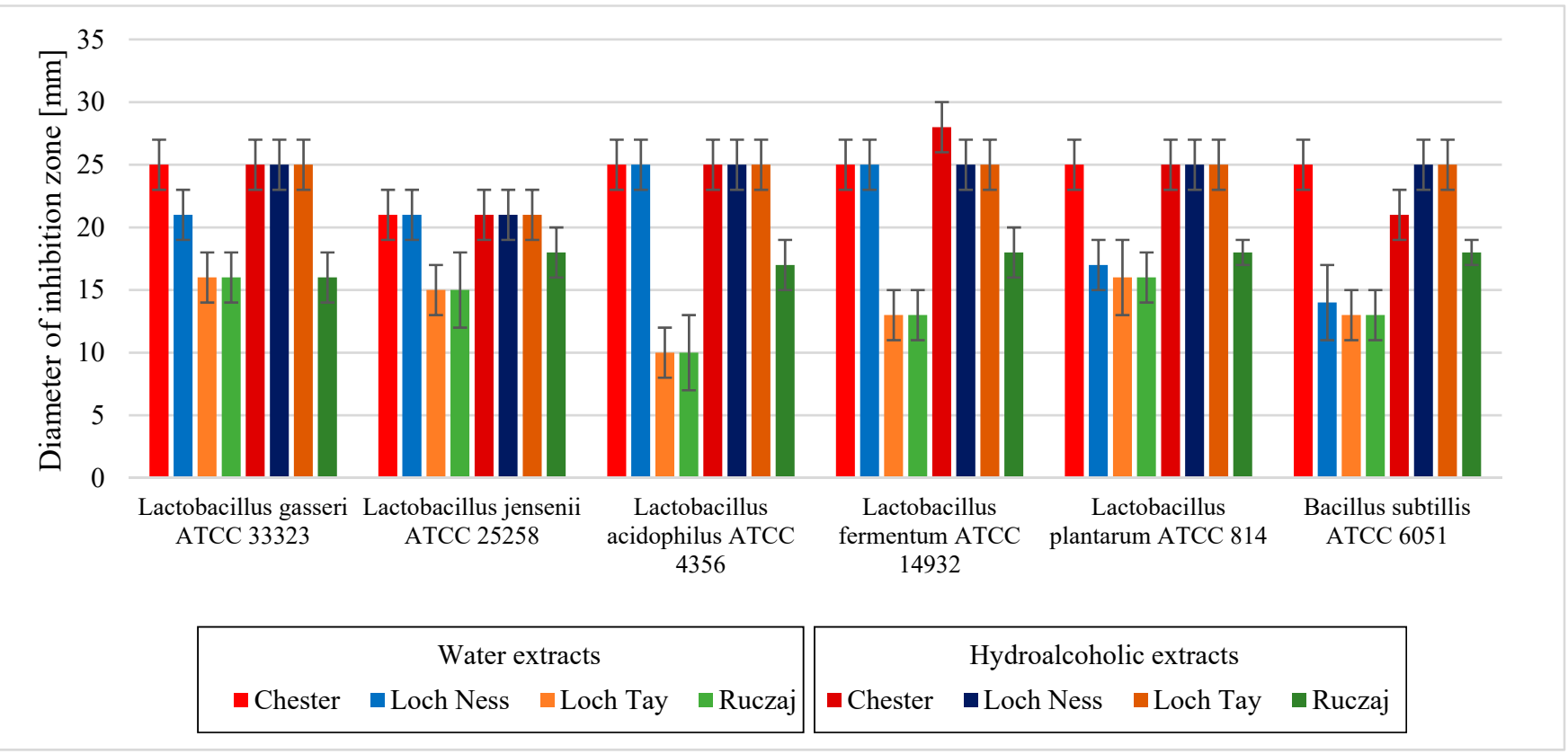

Figure 3. Microbiological activity of blackberry leaves extracts in their initial concentrations on health-promoting bacteria. Error bars define the SD values. 


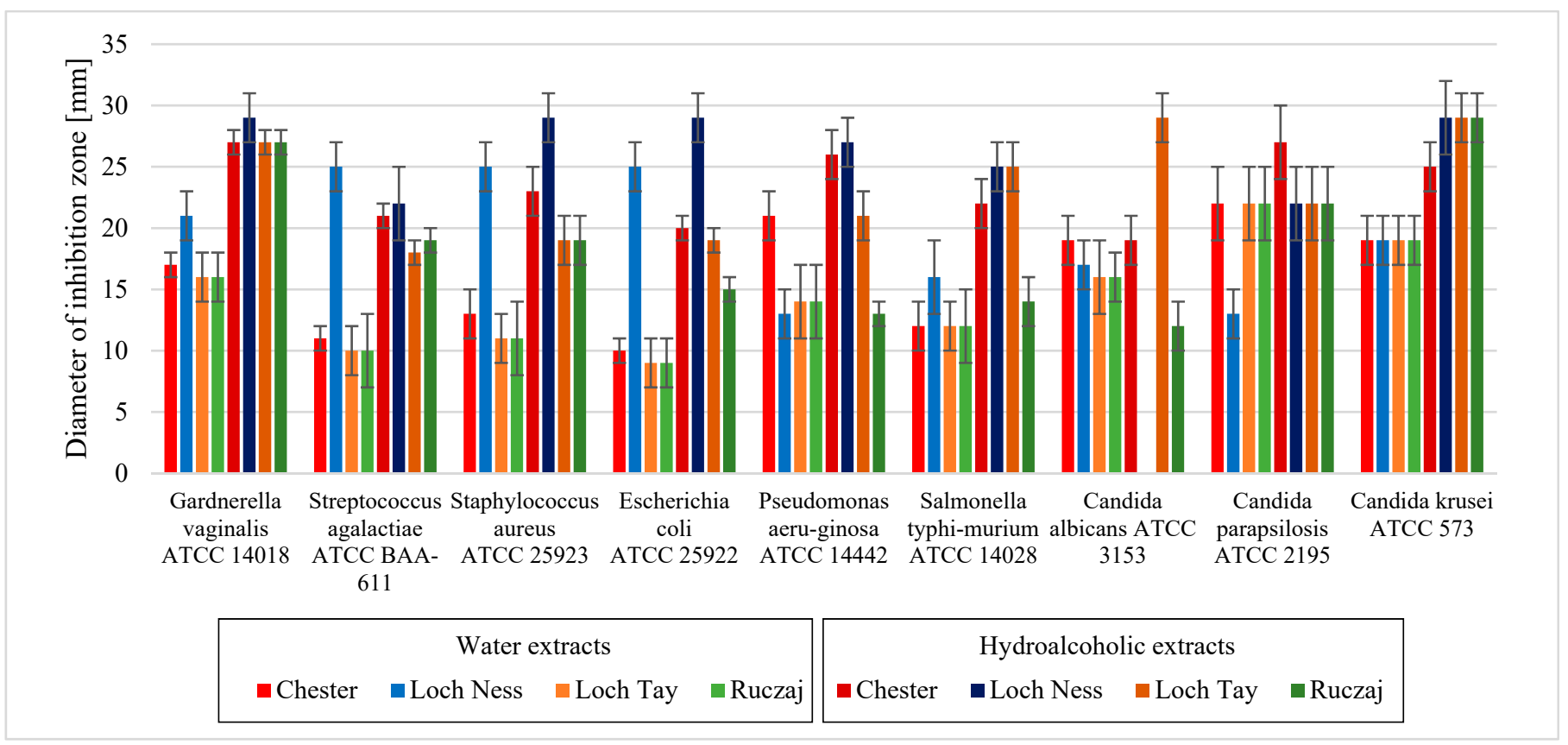

Figure 4. Microbiological activity of blackberry leaves extracts in their initial concentrations on potentially pathogenic microorganisms. Error bars define the SD values.

\section{Conclusions}

It was found that the content of the analyzed phytochemicals in blackberry leaf extracts depends on the type of extract, which is related to the solubility of individual components. Research has shown the comprehensive antioxidant activity of extracts, based on both free radicals' scavenging and metal-chelating activity; anti-inflammatory and antibacterial activity have also been proven. Based on numerous studies, the biological activity of all the tested varieties has been demonstrated to be broad, while the Loch Tay variety has been selected as the one with the greatest potential for biological activity, and its use in medicine may be further investigated. It can be assumed that the use of the leaves will be as beneficial to health as the consumption of fruit while reducing production costs and used as agri-food waste. Therefore, blackberry leaves may be a valuable new functional food as well as a source for development of new pharmaceutical formulations with standardized extracts.

Supplementary Materials: The following are available online at https: / www.mdpi.com/article/10 .3390/antiox10121945/s1, Table S1: Validation parameters for standard detected at $270 \mathrm{~nm}$, Table S2: Validation parameters for standard detected at $360 \mathrm{~nm}$.

Author Contributions: Conceptualization, M.P.-W. and J.C.-P.; methodology, M.P.-W., A.G., D.S. (Daria Szymanowska), D.S. (Dominik Szwajgier), E.B.-W. and P.S.; writing-original draft preparation, M.P.-W., D.S. (Daria Szymanowska), D.S. (Dominik Szwajgier), E.B.-W., P.S., D.D., M.S. and J.C.-P.; writing - review and editing, M.P.-W. and J.C.-P.; supervision, J.C.-P.; funding acquisition, M.P.-W. and J.C.-P. All authors have read and agreed to the published version of the manuscript.

Funding: This research was funded by a grant from the National Science Centre, Sonata, 2020/39/D/ NZ7/01824.

Institutional Review Board Statement: Not applicable.

Informed Consent Statement: Not applicable.

Data Availability Statement: The data is contained within the article or supplementary material.

Conflicts of Interest: The authors declare no conflict of interest. 


\section{References}

1. Hasler, C.M. Functional foods: Benefits, concerns and challenges-A position paper from the american council on science and health. J. Nutr. 2002, 132, 3772-3781. [CrossRef] [PubMed]

2. Ferlemi, A.V.; Lamari, F.N. Berry Leaves: An Alternative Source of Bioactive Natural Products of Nutritional and Medicinal Value. Antioxidants 2016, 5, 17. [CrossRef] [PubMed]

3. Kruczek, M.; Kostecka-Gugala, A.; Augustynowicz, J.; Ledwozyw-Smolen, I.; Orzel, A.; Krol-Dyrek, K.; Kaszycki, P. Raspberry and blackberry leaves as a raw material for pharmaceutical industry. Przemysl. Chem. 2015, 94, 1431-1436.

4. Zia-Ul-Haq, M.; Riaz, M.; De Feo, V.; Jaafar, H.Z.; Moga, M. Rubus fruticosus L.: Constituents, biological activities and health related uses. Molecules 2014, 19, 10998-11029. [CrossRef] [PubMed]

5. Vilariño, M.V.; Franco, C.; Quarrington, C. Food loss and Waste Reduction as an Integral Part of a Circular Economy. Front. Environ. Sci. 2017, 5, 21. [CrossRef]

6. Makris, D.P.; Sahin, S. Polyphenolic Antioxidants from Agri-Food Waste Biomass. Antioxidants 2019, 8, 624. [CrossRef] [PubMed]

7. Osorio, L.L.D.R.; Flórez-López, E.; Grande-Tovar, C.D. The Potential of Selected Agri-Food Loss and Waste to Contribute to a Circular Economy: Applications in the Food, Cosmetic and Pharmaceutical Industries. Molecules 2021, 26, 515. [CrossRef]

8. Farooq, M.U.; Mumtaz, M.W.; Mukhtar, H.; Rashid, U.; Akhtar, M.T.; Raza, S.A.; Nadeem, M. UHPLC-QTOF-MS/MS based phytochemical characterization and anti-hyperglycemic prospective of hydro-ethanolic leaf extract of Butea monosperma. Sci. Rep. 2020, 10, 3530. [CrossRef] [PubMed]

9. Faggian, M.; Bernabè, G.; Ferrari, S.; Francescato, S.; Baratto, G.; Castagliuolo, I.; Dall'Acqua, S.; Peron, G. Polyphenol-Rich Larix decidua Bark Extract with Antimicrobial Activity against Respiratory-Tract Pathogens: A Novel Bioactive Ingredient with Potential Pharmaceutical and Nutraceutical Applications. Antibiotics 2021, 10, 789. [CrossRef]

10. Smeriglio, A.; Denaro, M.; Trombetta, D.; Ragusa, S.; Circosta, C. New Insights on Euphorbia dendroides L. (Euphorbiaceae): Polyphenol Profile and Biological Properties of Hydroalcoholic Extracts from Aerial Parts. Plants 2021, 10, 1621. [CrossRef] [PubMed]

11. Oszmiański, J.; Wojdyło, A.; Gorzelany, J.; Kapusta, I. Identification and characterization of low molecular weight polyphenols in berry leaf extracts by HPLC-DAD and LC-ESI/MS. J. Agric. Food Chem. 2011, 59, 12830-12835. [CrossRef] [PubMed]

12. Patel, A.V.; Rojas-Vera, J.; Dacke, C.G. Therapeutic constituents and actions of Rubus species. Curr. Med. Chem. 2004, 11, 1501-1512. [CrossRef]

13. Abu-Shandi, K.; Al-Rawashdeh, A.; Al-Mazaideh, G.; Abu-Nameh, E.; Al-Amro, A.; Al-Soufi, H.; Al-Ma'abreh, A.; Al-Dawdeyah, A. A Novel Strategy for the Identification of the Medicinal Natural Products in Rubus Fruticosus Plant by Using GC/MS Technique: A Study on Leaves, Stems and Roots of the Plant. Adv. Anal. Chem. 2015, 5, 31-41.

14. Oszmiański, J.; Wojdyło, A.; Nowicka, P.; Teleszko, M.; Cebulak, T.; Wolanin, M. Determination of phenolic compounds and antioxidant activity in leaves from wild Rubus L. species. Molecules 2015, 20, 4951-4966. [CrossRef] [PubMed]

15. Commission of the European Comminities. Proceeding of the International Conference of Harmonisation. Validation of analytical procedures Q2(R2). 2018. Available online: https://www.ich.org/page/quality-guidelines (accessed on 3 December 2021).

16. Kikowska, M.A.; Chmielewska, M.; Włodarczyk, A.; Studzińska-Sroka, E.; Żuchowski, J.; Stochmal, A.; Kotwicka, M.; Thiem, B. Effect of Pentacyclic Triterpenoids-Rich Callus Extract of Chaenomeles japonica (Thunb.) Lindl. ex Spach on Viability, Morphology, and Proliferation of Normal Human Skin Fibroblasts. Molecules 2018, 23, 3009. [CrossRef] [PubMed]

17. Denev, P.; Kratchanova, M.; Ciz, M.; Lojek, A.; Vasicek, O.; Nedelcheva, P.; Blazheva, D.; Toshkova, R.; Gardeva, E.; Yossifova, L.; et al. Biological activities of selected polyphenol-rich fruits related to immunity and gastrointestinal health. Food Chem. 2014, 157, 37-44. [CrossRef]

18. Parschat, K.; Canne, C.; Hüttermann, J.; Kappl, R.; Fetzner, S. Xanthine dehydrogenase from Pseudomonas putida 86: Specificity, oxidation-reduction potentials of its redox-active centers, and first EPR characterization. Biochim. Biophys. Acta. 2001, 1544, 151-165. [CrossRef]

19. Moreira, P.R.; Maioli, M.A.; Medeiros, H.C.D.; Guelfi, M.; Pereira, F.T.V.; Mingatto, F.E. Protective effect of bixin on carbon tetrachloride-induced hepatotoxicity in rats. Biol. Res. 2014, 47, 49. [CrossRef] [PubMed]

20. Singh, R.P.; Padmavathi, B.; Rao, A.R. Modulatory influence of Adhatoda vesical (Justicia adhatoda) leaf extract on the enzymes of xenobiotic metabolism, antioxidant status and lipid peroxidation in mice. Mol. Cell. Biochem. 2000, 213, 99-109. [CrossRef]

21. Kozarski, M.; Klaus, A.; Nikšić, M.; Vrvić, M.M.; Todorović, N.; Jakovljević, D.; Van Griensven, L.J. Antioxidative activities and chemical characterization of polysaccharide extracts from the widely used mushrooms Ganoderma applanatum, Ganoderma lucidum, Lentinus edodes and Trametes versicolor. J. Food Compost. Anal. 2012, 26, 144-153. [CrossRef]

22. Öztürk, M.; Duru, M.E.; Kivrak, Ş.; Mercan-Doğan, N.; Türkoglu, A.; Özler, M.A. In vitro antioxidant, anticholinesterase and antimicrobial activity studies on three Agaricus species with fatty acid compositions and iron contents: A comparative study on the three most edible mushrooms. Food Chem. Toxicol. 2011, 49, 1353-1360. [CrossRef] [PubMed]

23. Ellman, G.L.; Lourtney, D.K.; Andres, V.; Gmelin, G.A. New and rapid colorimetric determination of acetylcholinesterase activity. Biochem. Pharmacol. 1961, 7, 88-95. [CrossRef]

24. Rhee, I.K.; van Rijn, R.M.; Verpoorte, R. Qualitative determination of false-positive effects in the acetylcholinesterase assay using thin layer chromatography. Phytochem. Analysis. 2003, 14, 127-131. [CrossRef] 
25. Szwajgier, D.; Baranowska-Wójcik, E. Terpenes and Phenylpropanoids as Acetyl- and Butyrylcholinesterase Inhibitors: A Comparative Study. Curr. Alzheimer Res. 2019, 16, 963-973. [CrossRef]

26. Studzińska-Sroka, E.; Dudek-Makuch, M.; Chanaj-Kaczmarek, J.; Czepulis, N.; Korybalska, K.; Rutkowski, R.; Łuczak, J.; Grabowska, K.; Bylka, W.; Witowski, J. Anti-inflammatory Activity and Phytochemical Profile of Galinsoga parviflora Cav. Molecules 2018, 23, 2133. [CrossRef]

27. Bhattacharya, K.; Chandra, G. Phagodeterrence, larvicidal and oviposition deterrence activity of Tragia involucrata L. (Euphorbiaceae) root extractives against vector of lymphatic filariasis Culex quinquefasciatus (Diptera: Culicidae). Asian Pac. J. Trop. Dis. 2014, 4, 226-232. [CrossRef]

28. Gudej, J.; Tomczyk, M. Determination of flavonoids, tannins and ellagic acid in leaves from Rubus L. species. Arch. Pharm. Res. 2004, 27, 1114-1119. [CrossRef] [PubMed]

29. Wang, S.Y.; Lin, H.S. Antioxidant activity in fruits and leaves of blackberry, raspberry, and strawberry varies with cultivar and developmental stage. J. Agric. Food Chem. 2000, 48, 140-146. [CrossRef] [PubMed]

30. Jazić, M.; Kukrić, Z.; Vulić, J.; Četojević-Simin, D. Polyphenolic composition, antioxidant and antiproliferative effects of wild and cultivated blackberries (Rubus fruticosus L.) pomace. Int. J. Food Sci. Technol. 2019, 54, 194-201. [CrossRef]

31. Buřičová, L.; Andjelkovic, M.; Čermáková, A.; Réblová, Z.; Jurček, O.; Kolehmainen, E.; Verhé, R.; Kvasnička, F. Antioxidant Capacity and Antioxidants of Strawberry, Blackberry, and Raspberry Leaves. Czech J. Food Sci. 2011, 29, 181-189. [CrossRef]

32. Priyadarsini, K.I.; Khopde, S.M.; Kumar, S.S.; Mohan, H. Free radical studies of ellagic acid, a natural phenolic antioxidant. J. Agric. Food Chem. 2002, 50, 2200-2206. [CrossRef] [PubMed]

33. Han, D.H.; Lee, M.J.; Kim, J.H. Antioxidant and apoptosis-inducing activities of ellagic acid. Anticancer Res. 2006, 26, 3601-3606. [PubMed]

34. Park, J.Y.; Han, X.; Piao, M.J.; Oh, M.C.; Fernando, P.M.; Kang, K.A.; Ryu, Y.S.; Jung, U.; Kim, I.G.; Hyun, J.W. Hyperoside Induces Endogenous Antioxidant System to Alleviate Oxidative Stress. J. Cancer Prev. 2016, 21, 41-47. [CrossRef] [PubMed]

35. Williamson, M.P.; McCormick, T.G.; Nance, C.L.; Shearer, W.T. Epigallocatechin gallate, the main polyphenol in green tea, binds to the T-cell receptor, CD4: Potential for HIV-1 therapy. J Allergy Clin. Immunol. 2006, 118, 1369-1374. [CrossRef]

36. Orhan, I.; Kartal, M.; Tosun, F.; Sener, B. Screening of various phenolic acids and flavonoid derivatives for their anticholinesterase potential. Z. Naturforsch. C J. Biosci. 2007, 62, 829-832. [CrossRef] [PubMed]

37. Szwajgier, D. Anticholinesterase activity of selected phenolic acids and flavonoids-Interaction testing in model solutions. Ann. Agric. Environ. Med. 2015, 22, 690-694. [CrossRef] [PubMed]

38. Marquina, M.A.; Corao, G.M.; Araujo, L.; Buitrago, D.; Sosa, M. Hyaluronidase inhibitory activity from the polyphenols in the fruit of blackberry (Rubus fruticosus B.). Fitoterapia 2002, 73, 727-729. [CrossRef]

39. Girish, K.S.; Kemparaju, K.; Nagaraju, S.; Vishwanath, B.S. Hyaluronidase inhibitors: A biological and therapeutic perspective. Curr. Med. Chem. 2009, 16, 2261-2288. [CrossRef]

40. El-Shitany, N.A.; El-Bastawissy, E.A.; El-Desoky, K. Ellagic acid protects against carrageenan-induced acute inflammation through inhibition of nuclear factor kappa B, inducible cyclooxygenase and proinflammatory cytokines and enhancement of interleukin-10 via an antioxidant mechanism. Int. Immunopharmacol. 2014, 19, 290-299. [CrossRef] [PubMed]

41. Kawakami, Y.; Hosokawa, T.; Morinaka, T.; Irino, S.; Hirano, S.; Kobayashi, H.; Yoshioka, A.; Suzuki-Yamamoto, T.; Yokoro, M.; Kimoto, M.; et al. Antiatherogenic effect of guava leaf extracts inhibiting leucocyte-type 12-lipoxygenase activity. Food Chem. 2012, 131, 1069-1075. [CrossRef]

42. Shukla, R.; Pandey, V.; Vadnere, G.P.; Lodhi, S. Chapter 18-Role of Flavonoids in Management of Inflammatory Disorders. In Bioactive Food as Dietary Interventions for Arthritis and Related Inflammatory Diseases, 2nd ed.; Watson, R.R., Preedy, V.R., Eds.; Academic Press: Cambridge, MA, USA, 2019; pp. 293-322.

43. Kim, S.J.; Um, J.Y.; Lee, J.Y. Anti-inflammatory activity of hyperoside through the suppression of nuclear factor- $\mathrm{k} B$ activation in mouse peritoneal macrophages. Am. J. Chin. Med. 2011, 39, 171-181. [CrossRef] [PubMed]

44. Morrison, M.; van der Heijden, R.; Heeringa, P.; Kaijzel, E.; Verschuren, L.; Blomhoff, R.; Kooistra, T.; Kleemann, R. Epicatechin attenuates atherosclerosis and exerts anti-inflammatory effects on diet-induced human-CRP and NFkB in vivo. Atherosclerosis 2014, 233, 149-156. [CrossRef] [PubMed]

45. Molan, A.L.; Lila, M.A.; Mawson, J.; De, S. In vitro and in vivo evaluation of the prebiotic activity of water-soluble blueberry extracts. World J. Microbiol. Biotechnol. 2009, 25, 1243-1249. [CrossRef]

46. Silva, S.; Costa, E.M.; Mendes, M.; Morais, R.M.; Calhau, C.; Pintado, M.M. Antimicrobial, antiadhesive and antibiofilm activity of an ethanolic, anthocyanin-rich blueberry extract purified by solid phase extraction. J. Appl. Microbiol. 2016, 121, 693-703. [CrossRef] [PubMed]

47. Weli, A.M.; Al-Saadi, H.S.; Al-Fudhaili, R.S.; Hossain, A.; Putit, Z.B.; Jasim, M.K. Cytotoxic and antimicrobial potential of different leaves extracts of $R$. fruticosus used traditionally to treat diabetes. Toxicol. Rep. 2020, 7, 183-187. [CrossRef] [PubMed]

48. Papuc, C.; Goran, G.V.; Predescu, C.N.; Nicorescu, V.; Stefan, G. Plant Polyphenols as Antioxidant and Antibacterial Agents for Shelf-Life Extension of Meat and Meat Products: Classification, Structures, Sources, and Action Mechanisms. Compr. Rev. Food Sci. Food Saf. 2017, 16, 1243-1268. [CrossRef]

49. Bouarab-Chibane, L.; Forquet, V.; Lantéri, P.; Clément, Y.; Léonard-Akkari, L.; Oulahal, N.; Degraeve, P.; Bordes, C. Antibacterial Properties of Polyphenols: Characterization and QSAR (Quantitative Structure-Activity Relationship) Models. Front. Microbiol. 2019, 10, 829. [CrossRef] 
50. Álvarez-Martínez, F.J.; Barrajón-Catalán, E.; Encinar, J.A.; Rodríguez-Díaz, J.C.; Micol, V. Antimicrobial Capacity of Plant Polyphenols against Gram-positive Bacteria: A Comprehensive Review. Curr. Med. Chem. 2020, 27, 2576-2606. [CrossRef]

51. González, O.A.; Escamilla, C.; Danaher, R.J.; Dai, J.; Ebersole, J.L.; Mumper, R.J.; Miller, C.S. Antibacterial effects of blackberry extract target periodontopathogens. J. Periodontal. Res. 2013, 48, 80-86. [CrossRef] 